\title{
Variability of Urinary Dapsone/Creatinine Concentration Ratios in Leprosy Patients Fully Compliant with Dapsone Therapy
}

\author{
KATHLEEN J. HAGAN and S. E. SMITH \\ Department of Pharmacology, St Thomas's Hospital Medical School, London SE1, U.K.
}

\begin{abstract}
A highly sensitive and reproducible assay procedure for the determination of dapsone (DDS) and hydrolizable metabolites in urine is described. DDS/creatinine (D/C) concentration ratios, which are used to monitor compliance with DDS therapy, have been determined on samples of all urine voided throughout a 24 -h period by 7 leprosy in-patients fully compliant with their therapy. The $\mathrm{D} / \mathrm{C}$ concentration ratios varied both within and between patients over the $24 \mathrm{~h}$ and the time-course of variation showed no closely predictable pattern. Urinary excretion of DDS over the $24 \mathrm{~h}$ was found to be $74.8 \% \pm 5.7 \%$ (S.E.M.) uncorrected or $90.2 \% \pm 6.8 \%$ corrected for recovery. Our results indicate an unreliability in the use of single urine samples to determine $\mathrm{D} / \mathrm{C}$ ratios and hence compliance by individual patients with their DDS therapy.
\end{abstract}

\section{Introduction}

A quantitative method by which dapsone (DDS) self-administration in leprosy patients can be monitored has been evaluated (Ellard, Gammon, Helmy and Rees, 1974a). The ratios of DDS to creatinine (D/C) concentrations in urinary samples are determined and a comparison made between the $\mathrm{D} / \mathrm{C}$ concentration ratios of patients taking DDS under strict supervision and those who administer their own medication. Ellard, Gammon and Harris (1974b), Low and Pearson (1974) and Huikeshoven et al. (1976) have applied this technique to determine the regularity of dapsone self-administration.

Prior to assessing in a large number of patients the regularity of DDS selfmedication based on measurement of $\mathrm{D} / \mathrm{C}$ concentration ratios, the reliability of the use of $\mathrm{D} / \mathrm{C}$ concentration ratios obtained on single urine samples has been examined. This paper describes the results of determinations on samples of all urine passed in $24 \mathrm{~h}$ by 7 patients. All patients are resident in a leprosarium in England where their DDS administration is strictly supervised.

\section{PATIENTS}

\section{Methods}

Seven leprosy patients ( 6 male, 1 female), resident in a leprosarium, volunteered for this study. All had been on long-term DDS therapy and had 
received their current dosage regimen ( $25 \mathrm{mg}$ or $50 \mathrm{mg}$ once daily) for at least 6 weeks. Five of the patients (numbers 1, 2, 5, 6 and 7) were receiving other drugs listed in Table 1.

\section{URINE SAMPLES}

All urine was collected during one 24 -h period. At each voiding the time was noted, a $25-\mathrm{ml}$ sample separated and the remainder placed in a collection bottle. Creatinine and DDS were determined in each voiding and in the $24 \mathrm{~h}$ save.

\section{CREATININE AND DDS DETERMINATIONS}

Creatinine was determined by the alkaline picrate method (Jaffe, 1886), using an automated procedure (Technicon Method No. SE4-0011FH4, 1974). DDS, as total diazotizable compounds, was determined in duplicate by the following method which is similar to that recommended by Varley (1967) and is a modification of the Bratton and Marshall (1939) procedure. Two-ml portions of each sample were acidified by addition of $2 \mathrm{ml} 2 \mathrm{~N} \mathrm{HCl}$ and immersed in a boiling water bath for $15 \mathrm{~min}$ to ensure hydrolysis of dapsone metabolites (Ellard, 1966). After cooling, $0.4-\mathrm{ml}$ volumes of $0.1 \%$ sodium nitrite, $0.5 \%$ ammonium sulphamate and $0.1 \%$ naphthylethylenediamine dihydrochloride (in $95 \%$ ethanol) were added successively at 5-min intervals. The optical density at $540 \mathrm{~nm}$ was measured $5 \mathrm{~min}$ after addition of the last reagent against a reagent blank using $5 \mu \mathrm{g} / \mathrm{ml}$ DDS standards. Urinary blank values were determined on each sample by substitution of water for sodium nitrite.

Recovery of DDS added to urine was $82.9 \% \pm 2.8 \%$ (s.E.M.) (range 69-91\%) and duplicate determinations showed satisfactory repeatability [Fisher's (1970) intrapair correlation coefficient $r>0.98$ ]. Urine from 13 normal untreated subjects yielded apparent DDS/creatinine concentration ratios of $1.10 \pm 0.20$ (range $0.20-2.95) \mu \mathrm{g} / \mathrm{mg}$.

All of the drugs listed in Table 1 and also the metabolites $\mathrm{N}$ demethylclindamycin and desmethyldiazepam were tested for interference with the DDS assay procedure. None of the drugs, except desmethyldiazepam, was found to react.

\section{Results}

Total DDS and creatinine excretion in $24 \mathrm{~h}$ and D/C concentration ratios of these totals, together with the ranges found among all urine samples, are given in Table 1. Urinary DDS excretion over $24 \mathrm{~h}$ was found to be $74.8 \% \pm 5.7 \%$ (S.E.M.) of the dose administered. After correction for an average recovery of $82.9 \%$ in the determination, this amounts to $90.2 \% \pm 6.8 \%$ of the dose.

DDS/creatinine concentration ratios of different urine samples varied widely both between and within individual patients. The variability encountered is shown in Fig. 1; it ranged from 1.44-fold (patient no. 7) to 4.49-fold (patient 
TABLE 1

Urinary excretion of $D D S$ and creatinine and $D / C$ concentration ratios in 7 patients: (a) 24 h excretion; (b) values for individual urine samples during $24 \mathrm{~h}$

\begin{tabular}{|c|c|c|c|c|c|c|c|c|c|c|}
\hline \multirow[b]{2}{*}{ Patient } & \multirow[b]{2}{*}{ Sex } & \multirow[b]{2}{*}{ Age } & \multirow[b]{2}{*}{$\begin{array}{c}\text { DDS } \\
\text { dosage } \\
\text { (mg/day) }\end{array}$} & \multirow[b]{2}{*}{$\begin{array}{l}\text { Other } \\
\text { drugs }\end{array}$} & \multicolumn{3}{|c|}{ (a) $24 \mathrm{~h}$ excretion } & \multicolumn{3}{|c|}{ (b) Range of individual values } \\
\hline & & & & & $\begin{array}{l}\text { DDS } \\
(\mathrm{mg})\end{array}$ & $\begin{array}{l}\text { Creatinine } \\
\text { (g) }\end{array}$ & $\begin{array}{c}\mathrm{D} / \mathrm{C} \\
\text { ratio } \\
(\mu \mathrm{g} / \mathrm{mg})\end{array}$ & $\begin{array}{c}\text { DDS } \\
(\mu \mathrm{g} / \mathrm{ml})\end{array}$ & $\begin{array}{l}\text { Creatinine } \\
(\mathrm{mg} / \mathrm{ml})\end{array}$ & $\begin{array}{c}\mathrm{D} / \mathrm{C} \\
\text { ratio } \\
(\mu \mathrm{g} / \mathrm{mg})\end{array}$ \\
\hline 1 & $\mathbf{M}$ & 62 & 25 & Diazepam & 14.9 & 1.30 & 11.5 & $3.1-19.3$ & $0.26-1.36$ & $9.4-16.2$ \\
\hline 2 & $\mathbf{M}$ & 46 & 25 & Erythromycin & 21.5 & 1.39 & 15.5 & $6.4-28.7$ & $0.40-2.10$ & $7.1-21.0$ \\
\hline 3 & $\mathbf{M}$ & 82 & 25 & nil & 16.6 & 1.31 & 12.7 & $3.1-39.8$ & $0.51-2.19$ & $5.4-24.2$ \\
\hline 4 & $\mathrm{~F}$ & 76 & 25 & nil & 23.0 & 0.74 & 31.1 & $8.2-61.0$ & $0.28-2.27$ & $19.5-33.3$ \\
\hline 5 & $\mathbf{M}$ & 50 & 50 & $\begin{array}{l}\text { Clindamycin } \\
\text { Indomethacin }\end{array}$ & 17.5 & 1.44 & 12.2 & $9.9-57.9$ & $0.91-2.04$ & $9.1-28.3$ \\
\hline 6 & M & 54 & 50 & Diazepam & 56.5 & 1.70 & 33.2 & $18.7-35.2$ & $0.64-1.73$ & $13.7-47.2$ \\
\hline 7 & $\mathbf{M}$ & 20 & 50 & Clofazimine & 36.8 & 1.21 & 30.4 & $23.0-58.4$ & $0.86-1.52$ & $26.6-38.3$ \\
\hline
\end{tabular}




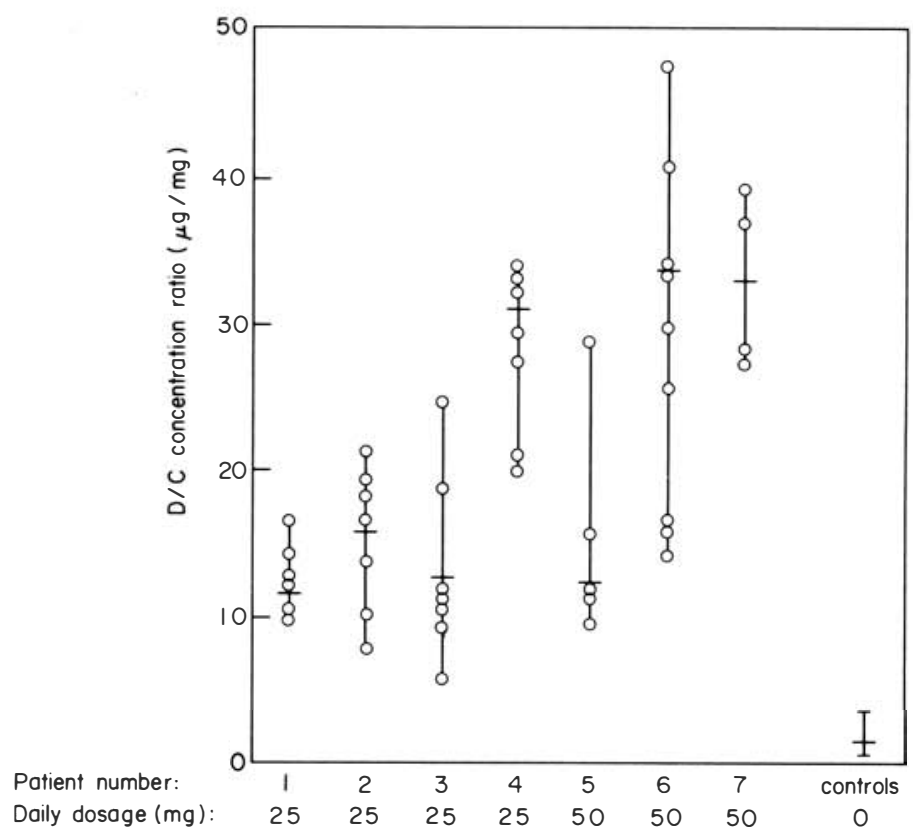

Fig. 1. Urinary DDS/creatinine concentration ratios $(\mu \mathrm{g} / \mathrm{mg})$ of all samples voided by 7 patients during $24 \mathrm{~h}$. Horizontal lines indicate $24 \mathrm{~h}$ values.

no. 3). In one subject (patient no. 3) D/C concentration ratios were found to differ 3-fold in urine samples voided within one 2-h period. Analysis of variance, using a nested classification, revealed that the differences observed were highly significant: viz. between patients, $P<0.01$; between times within patients, $P<0.001$ (Table 2). Inspection of the time course of $\mathrm{D} / \mathrm{C}$ ratios

TABLE 2

Analysis of variance of urinary DDS/creatinine concentration ratios.

Values shown in Fig. 1

\begin{tabular}{|c|c|c|c|c|c|}
\hline Source of variation & d.f. & $\begin{array}{l}\text { Sum of } \\
\text { squares }\end{array}$ & $\begin{array}{l}\text { Mean } \\
\text { square }\end{array}$ & $F$ & $P$ \\
\hline Between doses & 1 & 1871.92 & 1871.92 & \multirow{2}{*}{2.41} & \\
\hline $\begin{array}{l}\text { Between individuals } \\
\text { within doses }\end{array}$ & 5 & 3888.77 & 777.75 & & $\cap \Omega 1$ \\
\hline $\begin{array}{l}\text { Between } 12 \text {-h periods } \\
\text { within individuals }\end{array}$ & 7 & 459.55 & 65.65 & \multirow{2}{*}{$\begin{array}{r}11.85 \\
0.62\end{array}$} & 0.01 \\
\hline $\begin{array}{l}\text { Between times within } \\
12 \text {-h periods }\end{array}$ & 36 & 3843.47 & 106.76 & & - \\
\hline Within times (error) & 50 & 10.08 & 0.2016 & \multirow{2}{*}{529.58} & $<0.001$ \\
\hline TOTAL & 99 & 10073.79 & & & \\
\hline
\end{tabular}


through the 24-h period of collection revealed no clear pattern of variation and there was no significant difference between ratios during the first and second 12-h periods following drug administration.

\section{Discussion}

A highly sensitive and reproducible assay procedure for the determination of DDS and hydrolizable metabolites in the urine has been described. Attempts were made in our laboratory to follow the adaptation of the Bratton and Marshall method described by Ellard et al. (1974a). The formation of a fine purple precipitate in standard solutions of $30 \mu \mathrm{g} / \mathrm{ml}$ and over led to interference with spectrophotometry, making the assay imprecise. If the precipitate is due to the insolubility of the azo dye so formed, then a certain amount of alcohol must be added with or just before the coupling component, as suggested by Bratton and Marshall (1939). Our modification of the assay procedure showed highly satisfactory reproducibility. Urine from untreated subjects yielded apparent $\mathrm{D} / \mathrm{C}$ ratios of less than $3 \mu \mathrm{g} / \mathrm{mg}$; some published figures using other modifications have yielded ratios up to $10 \mu \mathrm{g} / \mathrm{mg}$. The present method therefore appears to be particularly applicable in studies of patients, such as ours, on low dosage regimens.

It was found that recovery of DDS added to urine samples of 10 normal subjects averaged $83 \%$. The recovery rates varied between samples, however, to an extent which might be expected to influence DDS concentrations in clinical samples to a minor degree, calculated as less than $30 \%$. No attempt has been made to measure recovery of the drug's acidic metabolites, which account for much of its total excretion (Ellard, 1966), so the clinical implication of this finding is at present incalculable.

DDS/creatinine concentration ratios of our patients were subject to substantial variability over the $24 \mathrm{~h}$, the greatest difference between $\mathrm{D} / \mathrm{C}$ concentration ratios within any one individual being $4 \frac{1}{2}$-fold. This range is somewhat greater than that indicated by the repeat sample study performed by Low and Pearson (1974), and it is too great to be explained by differences in recovery in the method. No clear reason for such variation is apparent. In particular we found no consistent diurnal change such as would be expected from once daily drug administration.

Two of the patients (nos 1 and 6) were treated with diazepam, the first metabolite of which, desmethyldiazepam (Hillestad et al., 1974) was found to yield colour with the assay procedure. Such interference is, however, unlikely to have contributed to the total variation in apparent DDS output because the metabolite has an elimination half-life of over $90 \mathrm{~h}$ and in such a case the urinary appearance of this compound and its further degradation products can change only minimally over the 24 -h period.

Our results demonstrate that with determinations on single urine samples errors in classifying individual patients as taking their dapsone regularly or irregularly will arise in those who normally have quite variable $\mathrm{D} / \mathrm{C}$ concentration ratios through the $24 \mathrm{~h}$. The reliability of using one urine sample obtained 
from the patient at a surprise visit to his home, as suggested by Ellard et al. (1974b) and carried out by Huikeshoven et al. (1976), is thus questioned. Our findings, however, do not invalidate the use of such samples in population studies from which general levels of patient compliance are deduced.

\section{Acknowledgements}

We are most grateful to Dr S. G. Browne, Dr D. J. Harman and Dr J. M. Pirrie for permitting this study on their patients and to Sister Gloria, Sister Felicity and the patients at the leprosarium who cooperated in the urine collection. We also thank the Clinical Chemistry Department at St Thomas's Hospital for allowing us facilities for automatic creatinine assays. The dapsone was kindly supplied by ICI Pharmaceuticals, desmethyldiazepam by Roche Products Ltd, N-demethylclindamycin by Upjohn Ltd, and clofazimine by Geigy Pharmaceuticals Ltd.

This study was financed by grants from Ciba Laboratories and St Thomas's Hospital Endowments, to whom we are greatly indebted.

\section{References}

Bratton, A. C. and Marshall, E. K., Jr. (1939). A new coupling component for sulfanilamide determination. J. biol. Chem. 128, 537.

Ellard, G. A. (1966). Absorption, metabolism and excretion of di(p-aminophenyl) sulphone (dapsone) and di(p-aminophenyl) sulphoxide in man. Br. J. Pharmac. 26, 212.

Ellard, G. A., Gammon, P. T., Helmy, H. S. and Rees, R. J. W. (1974a). Urine tests to monitor the self-administration of dapsone by leprosy patients. Amer. J. trop. Med. Hyg. 23, 464.

Ellard, G. A., Gammon, P. T. and Harris, J. M. (1974b). The application of urine tests to monitor the regularity of dapsone self-administration. Lepr. Rev. 45, 224.

Fisher, R. A. (1970). Statistical Methods for Research Workers, 14th edit. Edinburgh: Oliver and Boyd.

Hillestad, L., Hansen, T. and Melson, H. (1974). Diazepam metabolism in normal man. II. Serum concentration and clinical effect after oral administration and cumulation. Clin. Pharmac. Ther. 16, 485.

Huikeshoven, H. C. J., Honhoff, C., Van Eys, G. J. J. M., Anten, J. G. F., Mayer, J. M. A. and Van Helden, H. P. T. (1976). Weekly self-medication of leprosy patients monitored by DDS/creatinine ratios in urine. Lepr. Rev. 47, 201.

Jaffe, M. Z. (1886). Ueber den Niederschlag welchen Pikrinsäure im normalem Harn erzeugt und über einer neue Reaction des Kreatinins. Physiol Chem. 10, 391.

Low, S. J. M. and Pearson, J. M. H. (1974). Do leprosy patients take dapsone regularly? Lepr. Rev. 45, 218.

Technicon (1974). In Technicon Autoanalyzer II. Technicon Instruments Corporation, Tarrytown, New York.

Varley, H. (1967). In Practical Clinical Biochemistry, 4th edit., p. 745. London: William Heinemann Medical Books. 